\title{
The Potential of Social Media as a Communication Tool among Co-Operative in Kenya: A Review of Literature
}

\author{
Mwongela Francis*, Wenje Peres, Anyonje Lydia, John Kirimi M'Raiji \\ Masinde Muliro University of Science and Technology
}

*Corresponding Author: Mwongela Francis, Masinde Muliro University of Science and Technology

\begin{abstract}
Social Media has reshaped modern day public lives in communication by transforming and expanding the scopes of new potential networks and deepened existing networks.For the Co-operative movement to rejuvenate itself in the new communication era, adoption of new media may not be an option. To a large extent, and, globally, the Co-operative movement provides a platform for entrepreneurship, savings, credit facilities, job opportunities and further mechanisms for governance, innovations and trainings to the youth. The objectives of this study is to assess the potential of social media as a communication tool used by the Co-operatives in Kenya. Survey design was used backed by the Social Construction of Technology. The study found out that social media is a key communication tool with potential to revolutionize how cooperative societies operate.
\end{abstract}

Keywords: Internet, co-operative, communication, digital divide, new media, network

\section{INTRODUCTION}

Whereas the growth of Kenya's cooperative movement is steady and of prosperity, the sector is impeded by the limited use of technology, and business ideas involving Information Communication Technologies (ICTs) are being taken on by corporations and individual business people; a missed opportunity for the co-operative movement in Africa (Nyaga, 2014). It is documented that the Kenya's cooperative business model is the best in Africa and $7^{\text {th }}$ best in the Globe Further, the cooperative movement in Kenya mobilizes and controls over Kenya's 45\% of the GDP with about $84 \%$ of Kenyans deriving their livelihoods either directly or indirectly form the cooperatives (ICA, 2014).

Research has shown that the benefits of ICTs to cooperatives are numerous. Through fully utilizing the Social Media, cooperatives can cultivate new markets by reaching out to different customer bases on the online; they can keep up-to-date with developments and new innovations and receive training remotely. New Media can help transform the management of co-operatives by improving, communication, marketing and management practices, financial information and reporting and records management as well as create an online presence. These improvements help increase efficiency and lower operating costs (Tom, 2015).

Broadly, it is important to note that social media are defined as technologies that facilitate storage, retrieval, communication and the processing of information by electronic means, and include everything from: radio, satellite, television, telephones, computers, smart mobile/wireless phones, laptops, iPads, and the Internet (Manovich, 2001). It is also acknowledged that the role of ICTs in improving efficiency in the cooperative movement is enormous. Also, on the other hand, the challenges and barriers brought by and associated with ICT implementation are also tithing in the Cooperative development hence hindering the uptake (Kobia, 2011).

According to the UN International year of Cooperatives in June, 2012, it was postulated that, "ICT's are transforming co-operatives by expanding the scope of potential networks and deepening existing networks through more consistent communication.". The importance of building connections and communication among members and across organizations was stressed throughout the discussions by also highlighting the scale and uniqueness of cooperatives (UN, 2012):

"Co-operatives are a clearly identifiable group with an existing community of over a billion people and growing. They have unifying cooperative principles such as democratic member 
control, cooperation among co-operatives and concern for community which shape cooperatives approach to their members, their business and their communities".

The International Telecommunication Union (ITTU) liaison office of UN during the International Year of Cooperatives in 2012 notes that, "The missing link between the developed and developing world is access to communication. ICT networks are a catalyst for the achievement of all three pillars of sustainability; social, economic and environmental and ICT infrastructure is taking on a utilitarian function on par with water, energy and transportation. $26 \%$ of all GDP growth in developing countries can be attributed to the internet. Mobile telephony is almost $100 \%$ so the divide now has shifted to access to the internet and access to mobile broadband because that's where the future is going to be" (UN, 2012).

In his Book, African Minister's Lessons for Co-operatives, Nyaga, argues that the cooperative movement in Kenya remains a key driver in economic empowerment, job creation and poverty alleviation, the youth are conspicuously missing (Nyaga, 2014). Further research, has shown that, in Kenya, there is increasing membership of women in cooperatives as compared to men without mentioning the dwindling numbers of the youth (Wanyama, 2014).

Despite the fact that cooperative enterprises provide livelihoods for millions of people around the world, and are by nature sustainable and participatory forms of businesses, they have remained invisible most probably due to lack of understanding of the actual and potential contribution the can make to sustainable businesses, and development (Wanyama, 2014).

It is argued that Co-operatives in Kenya, over the years have experienced various challenges; among them corruption and hence the need to introduce more Information Communication Technology (ICT) to curb such problems.

Globally, co-operatives are gearing up to internet ownership a fact that perhaps may leave African cooperatives behind in the future of co-operatives. This new dimension of internet platforms and case in point 'platform cooperativism' will challenge the corporate sharing economy. A Canadian researcher Tom Slee, in What's Yours Is Mine argues that,

Many well intentioned people suffer from a misplaced faith in the intrinsic abilities of the internet to promote egalitarian community and trust, and so have unwittingly aided and abetted accumulation of private fortune, and the construction of new and exploitative forms of employment. (Tom, 2015).

\section{Statement of the Problem}

Few studies in Africa have been conducted to assess uptake of social Media by Cooperatives. From some of these studies, Concerns have been raised over the low uptake and adoption of ICTs as a communication tool among cooperatives creating a huge entrepreneurial gap among members of cooperatives (Bwisa, 2010). This therefore then, has created a debate on what role and how the social media, as a communication tool (Okwany, 2010). Whereas ICT remains a key component in all sectors of the economy and remains a key driver of businesses and enterprises in the digital world, its uptake among other sectors of the economy across Africa has had significance in positive growth of those sectors a case in point the banking sector and the mobile money transfer services like Mpesa in Kenya which is a recent development compared to the existence of the co-operative sector (FSD, 2015). This disparity is a case in point which requires address.

It is arguable that the extent to which Social Media can change business operations and the bottom line in a year is undisputed. Think about it; ten years ago, there were no smart phones. Three years ago, few people knew about the cloud computing. Some years ago, one could swipe a credit card without fear of being left vulnerable if a transaction turns into fraud. Even, day-to-day business operating systems such as online accounting software are moving to the cloud; flexibility like this allows business owners to process invoices and manage cash flow on the go (FSD, 2015).

A Canadian researcher Tom Slee, argues that inasmuch as demand and usage of social media remains high for efficiency and productivity, its uptake remains low in co-operative sectors in Africa where the youth who are synonymous with it, lack representation and their participation in cooperative ventures remain low (Tom, 2015). Therefore, then, on this basis there is need to provide information 
and new knowledge on where the co-operatives stand is in terms of utilization of social media as a source of co-operative information among the youth.

\subsection{Main Objective}

The main objective for this study was to investigate the potential of social media of social media as a communication tool among cooperatives in Kenya.

\section{Specific Objectives}

- To assess the extent to which Co-operatives in Kenya have adopted and utilized Social Media as a communication tool

- To explore opportunities for utilization of Social Media as a communication tool

\subsection{Research Questions}

This study seeks to answer the following research questions:

- To what extent have Co-operatives adopted and utilized Social Media as a communication tool in cooperatives

- What are opportunities for utilization of Social Media as a communication tool among cooperatives

\section{JUSTIFICATION OF THE STUDY}

This study sought to break the parallel between two fast growing sectors in Kenya; social media adoption and Co-operatives. By the co-operatives in Kenya increasing their uptake of social media as a communication tool, innovativeness, and the youth increasingly using the social media to communicate especially in setting the social agenda is apparent to the study. Although co-operatives have increasingly shown signs of adopting social media as a source of co-operative information, these messages may not be specifically tailored towards creating a one stop shop of co-operative information. By co-operatives integrating the principles and values they hold, in the digital world, they can use social media as a convenient, cost-effective platform of information.

The co-operative movement therefore needs to position itself in the digital world to tap into the potential benefits of social media as a platform to offer information. Research findings have shown that that social Media can play a big role in provision of information that would be vital in the development of cooperatives but there are some challenges to be overcome, namely cost and infrastructure issues relating to access. Although access to telephone communications is now widely available all over the world, many rural communities still don't have reliable access to the internet and mobile broadband. In areas with little or no internet access, awareness of the benefits of ICT is also a challenge and getting smaller cooperatives to bridge the digital divide is important (Nyaga, 2014).

Across the world, it has been recognized that the Cooperative enterprises are today's main engine of social and economic growth. Across board, co-operatives in Africa have big gaps in ICT uptake, yet technology helps in enhancing linkages, social capital and coordination of activities for common interests. In Africa, there is little data available in relation to the number of co-operatives embracing ICTs, the inherent opportunities and the challenges that go with this. Many co-operatives have no websites or social media pages, and have poor management of data for networking, marketing and for record purposes; for instance, farming co-operative might have produce but lacks buyers because the products are not adequately advertised (Bwisa, 2010).

\section{Conceptual ReView}

\subsection{The Concept of Communication}

According to Business Dictionary, Communication is thetwo-way process of reaching mutual understanding, in which participants not only exchange (encode-decode) information, news, ideas and feelings but also create and share meaning. In general, communication is a means of connecting people or places. In business, it is a key function of management; an organization cannot operate without communication between levels, departments and employees. (http://www.businessdictionary. com/definition/communication.html). 
There are two broad types of communication: verbal and non-verbal communication; of these, there is interpersonal communication which is the communication between two or more people in an organization (McQuail, 2002). Interpersonal communication includes various forms of communication, whether electronic, nonverbal or verbal key in any organization (Griffin, Et Al, 2014). The key elements in interpersonal communication are the communicator, the receiver, the perceptual screens, and the message. In communication, perceptual screens are defined as windows through which we interact with people that impact the quality, accuracy, and clarity of the communication (McQuail, 2002). The message contains the thoughts and feelings that the communicator intends to evoke in the receiver. Feedback in communication is an important loop, which occurs when the receiver provides the communicator with a response to the message (Griffin, Et Al, 2014).

Communication scholars assert that listening is an important aspect of communication process. In this, active and passive listening. Active listening is a skill that helps the receiver and communicator clearly and fully understand the message sent, one fully participates in the listening giving it full attention. It can be characterized as personal, feeling oriented, and responsive (McQuail, 2010). Active listening techniques cannot be used in electronic mail because nonverbal cues are absent and written affirmation is delayed. The following techniques can be used to increase active listening skills (Griffin, Et Al, 2014).

A positive response is a verbal recognition by the receiver that he/she is following the topic. Students may understand this technique by thinking about giving presentations and recalling an individual they focused on who was smiling, or nodding his or her head for reassurance (McQuail, 2002). When an individual paraphrases what $\mathrm{s} /$ he has heard, it helps clarify the information for the receiver as well as clarifying for the presenter what was not expressed well (Richard \& Lynn, 2013).

It has been observed that different cultures use silence in a communication context differently; to some, it is an approach to increase the ability for active listening (Griffin ,E., Et Al, 2014). It is argued that eye contact is a strong nonverbal communication device that requires delicate balance. Too little eye contact suggests lack of attention; too much eye contact conveys intimidation. Twoway communication is more desirable in organizations because it allows for reflective listening. For instance, Problem solving and decision making is a two-way communication. In a One-way communication, a message is sent to another person with no direct opportunity for clarifications, questions, feedback, or interaction. In contrast, two-way communication allows the communicator and receiver to interact (McQuail, 2010).

Studies have shown that good communication skills are critical for managers; managers who score high on communication have also been found to be higher performing managers. Further, it is been observed that there are five keys to effective managerial communication (Debra, 2016). Better managers tend to be more comfortable expressing their thoughts and feelings than are other managers (Griffin ,E., Et Al, 2014).

It is argued that empathetic listeners are able to determine the feelings and emotional dimensions of others, as well as their content regarding the ideas and issues. This communication skill depends heavily on active listening (McQuail, 2002).

\subsection{The Concept of Language and Social Media}

It is argued that language is one of the greatest inventions that man ever had in civilization and during prehistory. It is this discovery that over the years has made communication an innate aspect of humanity. Channels of communication however, have been in constant evolution just as language has been. Further, scholars have argued that Media, has, emerged out of growth of humanity and development since antiquity (P. Meiller 2009). It has become one of the major channels of communication henceforth; that notwithstanding, mainstream has been a domineering as a communication, which include broadcast media (Television and Radio) as well as print media (newspapers, reviews, magazines among others).

The elites in Africa own and control the mainstream media to their advantage either economically, socially or politically. To this end, Mainstream media has been accused of manufacturing consent; manipulating and relaying information that represent the interest of their owners and the ruling class 
especially in $3^{\text {rd }}$ world nations. The ruling class enjoys media protection and political economy. The ownership of the media houses is split between political actors which have given the Kenyan media a long continued support in terms of buying space and airtime for advertising.

It is worth noting that the new media which has also referred to as social media, has entered the stage and completely revolutionizing communication in terms of time, and content. It has complemented main stream media in relaying information to the masses. The mostly used social media platforms include; Facebook, Twitter, Whatsapp, Google chat, Skype, Yahoo chat Instagram, MySpace, LinkedIn among others. In March 2010 there were a little over two million Facebook accounts according to the Communication Council of Kenya CCK; in 2014, this number has doubled to slightly 4 million accounts in Kenya. This accounts for about 9 percent of the entire population. A great majority of those on social media are the youth (Kaplan, M. and Michael Haenlein, 2010). Of great note is that according to a CCK, report, as of September 2017, a total of 12 million Kenyans were on Whatsapp with 7.1 million of them being on Facebook (CCK, 2018).

The popularity of Facebook has been attributed to the easy access from cell phones and other gizmos; there is a Short Message Service SMS to Facebook for instance, that sends a text to the users on every time something happens on Facebook. There is also an application called Facebook zero, a text only free version of Facebook launched in 2010 in collaboration with mobile providers, which has brought Facebook to a larger number of people who prior to that did not have access to it.

Social media is also accessible by via computers that are internet enabled or connected. Computer literacy levels in Kenya have also grown tremendously in the $21^{\text {st }}$ century. The 2008 Consumer Insight Limited study reported that 74 percent of the population in Nairobi had used a computer at least once in their lifetime (CIL, 2008). Back in 2009, Synovate, on other hand had estimated that in 30 percent of the Kenyan urban population used the internet weekly (ITU, 2010).

Twitter is a social networking site more or less like Facebook; the only difference is that Tweets, (twitter messages), have a maximum of 280 characters long in all languages except Chinese, Korean and Arabic; this is contrary to earlier 140 characters signifying growth and development. Facebook has a limit of 5,000 friends for every member account, there are no such limits on followers on one's Twitter handle. However, on Facebook, one can have a fun-page with limitless likes or a group which can also have many likes.

Like the mainstream media, social media is also powerful in shaping opinions and setting public agenda. As such, on political undertones, social media can ignite violent conflicts in a nation. The discourse surrounding social media has been characterized as a duel of anecdotes between cyber utopians and cyber skeptics (Kwamchetsi, 2010)).

Respectively, they view the social media's rapid growth in popularity as a catalyst that will inevitably lead to more transparency in governance and democracy, and conversely the elitist protagonists, only see the danger that uncontrolled communication might pose to a country, nation or a society. Notably, the Arab spring and uprisings in the Middle East and North Africa in early 2011 has prompted calls on the need of rigorous study into the potential role social media can play in the economic, social and political lives (Kaplan, M. and Michael Haenlein 2010).

Recognizing the power of social media, in that their contents are uncensored, the governments made asserting controls over social media platforms a top priority as a reactionary measure to coil violence. For instance, Former Egyptian president Hosni Mubarak banned access to Twitter, Facebook, YouTube and Google in the first few days of the protest, he then shut down internet on $28^{\text {th }}$ January 2011. Former Libyan ousted leader president Gaddafi's security officers blocked all internet traffic in and out of the country, in response, the international community redirected funds towards programs that aimed at strengthening media in the North African region. These leaders, viewed social media wave as the trailer to hate messages spiking revolts to their unprecedented revolutionary fate and imminent ousters.

However, to the contrary, on the legal aspect, Article 20 of the ICCPR remains unclear and problematic on issues that may qualify as hate messages. A further elaboration of the ICCPR standards needs to be developed to define hate messages. Courts, all of over the world; both at the domestic and international levels, Africa included, have grappled with these issues with an array of 
results. At the domestic levels, countries have not been able to develop clear definition in their disparate bodies of laws. Similarly, domestic courts have not given any consistent interpretation of what may be constitutive components of speech as such to be defined as "promotion of national, racial or religious hatred that constitutes incitement to prejudice, antagonism or violence." However, some law enforcement agencies in various countries may be seen to be pro-government of the day; they tend, at times to brand any political speech they do not agree with as geared at incitement to hatred (ICCPR, 1996).

\subsection{The Concept of Social Media}

Social media refers to the means of interaction among people in which they create share and or exchange information ideas in virtual communities or networks using technology based applications. Micheal Heanlein defines social media as a group of internet based applications that build on the ideological and technological foundations of the web and that allow the creation and exchange of user-generated content. The content might include text, video, images, podcasts and other multimedia communications. The most prominent examples of social media include, Facebook, Twitter, Linkedin, Reddit, Google + Google talk, Yahoo chat, Skype, WhatsApp (Kaplan, M. and Michael Haenlein 2010).

Facebook is a popular free social networking website that allows registered users to create profiles, upload photos and video, send messages and keep in touch with friends' family and colleagues. Twitter is a free micro blogging service that allows registered members to broadcast posts called tweets. Twitter members can broadcast tweets and follow other user's tweets by using multiple platforms and devices. Wikipedia is a free, open content encyclopedia created through the collaborative effort of a community called the 'Wikipedians'. Anyone registered on the site can create an article for publication. Registration is not required to edit articles.

Furthermore, social media depends on mobile and web-based technologies to create highly interactive platforms through which individuals and communities share co-create discuss and modify user generated content. It introduces substantial and persuasive changes to communication between organizations communities and individuals. It is argued that social media has introduced positive effects such as allowing the democratization of the internet while also allowing individuals to advertise and form friendship. Much of criticism of social media has been that it has decreased faceto-face interactions, there have been issues of trustworthiness and reliability of information presented, concentration, ownership of media content, and the meaning of interactions created by social media.

\subsection{Communicating Through Communication Technologies}

It has been observed that many people avoid written communication perhaps because they do not believe they are skilled in expressing their thoughts in writing. It is also considered less personal in many situations. Written communication has the advantage of high to moderate information capacity, but may also have the disadvantage of moderate to low information richness (McQuail, 2002).

Communication Technologies include electronic mails, voice mail, fax machines, tablets, iPads and cell phones. While these technologies greatly enhance the speed of communication, they cannot convey the nonverbal cues that make up a significant portion of the message therefore limiting sometimes the understanding of a message (Richard W. \& Lynn H., 2013).

It has been observed that communication technologies affect human communication behavior and continue to do overtime. For instance, these technologies are typically more impersonal, and may result in less patience with one-to-one communication as a much slower form of communication. New technologies provide the opportunity for us to multitask, which may have drawbacks when we need to focus closely on one problem at a time (McQuail, 2002). We can be overloaded with information and will need to be more conscious of filtering information (Richard \& Lynn, 2013).

\subsection{New Media as a Communication Tool}

Robert Logan in his book, Understanding New Media: Extending Marshall McLuhan defines new media as mediums that are interactive, incorporating two-way communication and involve some form of computing, He further argues that New media is "very easily processed, stored, transformed, retrieved, hyperlinked and, perhaps most radical of all, easily searched for and accessed." He argues 
that a distinction between new media and old media is that old media is for the most part mass media. In addition, each form of new media is highly interactive, while mass media is not. Users of new media are active producers of content and information, whether sending an email or using Internet collaboration tools (Logan, 2010).

New media theorist Lev Manovich describes new media as being native to computers or relying on computers for distribution: websites, human-computer interface, virtual worlds, virtual reality, multimedia, computer games, computer animation, digital video, special effects in cinema and interactive computer installations (Manovich, 2001).

Contrasted with the old media, the "old media," consists of mainly print, radio, and television/movies, we see that their presence in our lives and our societies was limited to a few places. For example, television and radio have long been key technology meant for mass consumption while new media, are, however, more personal and more social than old media (McQuail, 2002).

In the book New Media, 1740-1915, media is examined as "a cultural process that involves not only the actual transmission of information but also the ritualized collocation of senders and recipients," according to editors Lisa Gitelman and Geoffrey Pingree. Thus, new media reflects societal values and societal transformation.

\subsection{The Future of New Media}

Arguments have been put forth that new media has shortened the distance among people all over the world through electronic communication; people can interact with each other anytime and anywhere. It is further argued that As a result of the evolution of new media technologies, globalization occurs (McQuail, 2002). Observations have been made that new media will continue to evolve in the information technology age. For instance, content could transform from a passive object that is acted upon by the audience to an intelligent, responsive and reactive item. This real-time content could be able to "read" the audience and use real-time feedback to change what is delivered to readers, listeners and viewers. Specific technologies, such as virtual reality, are also expected to shape the future of new media (Montfort, \& Fruin, 2003).

\subsection{The Evolution of New Media}

New media has emerged from old media's analogue concept; Communication scholars argue that New Media couldn't exist without the move from analogue to digital technology since all the types of new media are digitally based (Siapera, 2012). Digital media are designed to read numerical codes. Analogue media are created by encoding information onto a physical object that must then be paired with another device capable of reading that specific code (Lüders, 2008). So what mostly distinguishes analogue media from digital media are their physicality and their need to be matched with a specific decoding device (Siapera, 2012). Analogue media are a combination of mechanical and physical parts, while digital media could be completely electronic. (Montfort \& Fruin,2003).

Further, New media has changed how music is consumed; for instance music files are stored electronically and can be played on many different platforms, including iPods, computers, and smartphones. Analogue media like videocassette recorders (VCRs) are only compatible with specific media objects that have been physically encoded with information (Siapera, 2012).

The term New Media itself has been critiqued for setting up a false dichotomy between new and old (Siapera, 2012). The technology that made new media possible has been in development for many years. The Internet has existed in some capacity for more than forty years, and the World Wide Web, which made the Internet accessible to the masses (Montfort \& Fruin, 2003).

Despite the rapid changes in technology, the multiplatform compatibility of much of new media paradoxically allows for some stability (Montfort \& Fruin, 2003). Whereas new technology often made analogue media devices and products obsolete, the format of much of the new media objects stays the same even as newer and updated devices with which to access digital media become available. Key to new media is the notion of technological convergence (Lüders, 2008). Most new media are already digital, and the ongoing digitalization of old media allows them to circulate freely and be read/accessed/played by any digital media platform without the need for conversion (Siapera, 2012). 


\subsection{Social Media Today}

Media and more often mass media have long been discussed as a unifying force in the society owing to the roles that the media can play. However, it has been noted that inasmuch as the media continues to play these roles, it can be abused. large audience are most of the time connected to the same radio or television broadcast, newspaper story, book, or movie via a one-way communication channel sent from one place to many. It is worth noting that online media connects mass media outlets to people and allows people to connect back to them (Siapera, 2012).

The internet can be singled out as the basis for this connectivity; it connects individual computers, smartphones, and other devices in an interactive web, and it is this web of connected personal media devices like computers, mobile phones and smartphones that facilitates and defines social media (Lüders, 2008). Arguments have been advanced that technology has allowed for mediated social interaction since the days of the telegraph, but these connections were not at the mass level they are today. So even if we think of the telegram as a precursor to a "tweet," we can still see that the potential connection points and the audience size are much different. While a telegraph went to one person, a tweet can instantly go to millions of online people (Siapera, 2012).

The potential for social media was realized under the conditions of what is called Web 2.0; a new way of using the connectivity of the Internet to bring people together for collaboration and creativity-to harness collective intelligence (O'Reilly, 2012). This involves using the web to collaborate on projects and problem solving rather than making and protecting one's own material (Boler, 2008). It is worth noting that much of this was achieved through platforms and websites such as Napster, Flickr, YouTube, and Wikipedia that encouraged and enable user-generated content. It is important to note that user-generated content and collaboration have been a part of the World Wide Web for decades, but much of it was in the form of self-publishing information such as user reviews, online journal entries, and later blogs, microblogs, which cross over between the "old" web and Web 2.0 (O'Reilly, 2012).

The most influential part of the new web is social networking sites (SNSs), which allow users to build a public or semipublic profile, create a network of connections to other people, and view other people's profiles and networks of connections (Boyd \& Ellison, 2008). Although SNSs have existed for over a decade, earlier iterations such as Friendster and MySpace have given way to the giant that is Facebook. Facebook, which now has more than 2.07 billion active users per month as at $3^{\text {rd }}$ quarter of 2017 (Facebook, 2017); this number had been predicted to be one billion by the end of 2012 (Hunter, 2012).

More specific SNSs like LinkedIn focus on professional networking. In any case, the ability to selfpublish information, likes/dislikes, status updates, profiles, and links allows people to craft their own life narrative and share it with other people (Lüders, 2008). Likewise, users can follow the narratives of others in their network as they are constructed. The degree to which we engage with others' narratives varies based on the closeness of the relationship and situational factors, but SNSs are used to sustain strong, moderate, and weak ties with others (Richardson \& Hessey, 2009).

Social media enable interactivity between or and among individuals that share a social network. It also allow people to broadcast or narrowcast their activities and interests (Lüders, 2008). Over the years, social networking sites have grown tremendously as a form of open source publishing. Open source publishing first appeared most notably with software programs (O'Reilly, 2012). The idea was that the users could improve on openly available computer programs and codes and then the new versions, sometimes called derivatives, would be made available again to the community.

The advent of these new, collaborative, participative, and democratizing media has been both resisted and embraced by old media outlets. The increased participation and feedback means that traditional media outlets that were used to one-way communication and passive audiences now have to listen to and respond to feedback, some of which is critical and negative (Lüders, 2008). They want to encourage audience participation, but they also want to be able to control and predict the media consumption habits and reactions of audiences (Siapera, 2012).

In virtually all careers, one is likely to interact with something that is "open source." It maybe some type of open source software, since that is the area in which open source product development is most 
commonly applied (Brabham, 2008). When something is open source, its essential elements are available to anyone who may want to use and/or improve on the product. When a software is open source, for instance, the code is available to anyone who may want to edit it as long as they continue the open philosophy of product development by then making their version, often called a derivative, available to anyone who may want to edit it (Lüders, 2008). Within this philosophy, the synergy that is created when a group of people with different levels of knowledge, experience, and expertise work collaboratively leads to innovative ideas and products that are then shared with the commons rather than kept as proprietary. Mozilla's Firefox web browser is an example of free open source software (O’Reilly, 2012).

\subsection{Co-operatives}

According to the International Co-operative Alliance (ICA), a co-operative is defined as a business voluntarily owned and controlled by its members and operated for them and by them on a non-profit or cost basis (ICA, 2014). And consequently, the persons who own a co-operative also use it. Ouma, argues that a co-operative is organized and incorporated to engage in economic activities with certain ideals of democracy, socio-consciousness and human relations included (Ouma, 1989).

Further, the International Co-operative Alliance argues that Co-operatives are autonomous associations formed and democratically directed by people who come together to meet common economic, social, and cultural needs. Founded on the principle of participatory governance, cooperatives are governed by those who use their services; its members. As such, cooperatives are based on the principles of member empowerment, education, and community; co-ops operate laterally promoting participation both within their own organization, and through a focus on community interaction, and support (ICA, 2004).

Also, a co-operative is defined as an organization established for the purpose of purchasing and marketing the products of its members, i.e., shareholders, and/or procuring supplies for resale to the members, whose profits are distributed to the members (in the form of patronage dividends), not on the basis of the members' equity investment in the cooperative, but in proportion to their patronage of it, i.e., the amount of business that each member transacts with it. In a workers' cooperative, the members jointly manufacture a product and share in the profits of the enterprise based on the amount of labor they contribute (Kimberly \& Robert, 2004).

As such, the definition of cooperative varies depending on whether you are looking at it from the perspective of a cooperative activist, a cooperative scholar, a government official or such. A cooperative activist would perhaps argue that any organization that is committed to and practices cooperative principles is a cooperative. However, a corporate lawyer would probably say that a cooperative must be formed under a cooperative laws and principles (Kimberly \& Robert, 2004).

\section{REVIEW OF RELEVANT THEORY}

\subsection{The Social Construction of Technology Theory}

The Social Construction of Technology, is abbreviated as SCOT and for the purposes of this study, it will remain so. The phrase 'Social construction' was first used by Berger and Lukemann in 1996 in their 'treatise in the sociology of knowledge' (Bijker, 2010). Schutz argues that the social construction should be the object of social knowledge as reality is socially constructed. It is worthwhile to note that in the 1970s, social constructions of scientific facts were first developed and then followed by the social construction of artefacts (Schutz, 1943).

Social construction of technology (SCOT) helps us organize our activities by conceptualizing the hardness of obduracy of technology. Because we now live in a technological culture, SCOT offers a conceptual framework for putting issues on the political agenda. (Wajcman, 2000). Society including politics is technically built as technology since technology is socially and politically constructed. (Wajcman, 2000).

The Social construction of technology theory was developed by Trevor Pinch and Wieber Bijker in the 1980s. This theory has gained advantages in analyzing users as agents of technological change. Relevant social groups who are involved in the development of artefacts in SCOT are defined as the groups who share meaning of the artefact and this meaning can be used to explain particular 
development paths (Kline and Pinch, 1996). It is argued that a social group can consist of the media, technologists, communicators, consumers, etc. SCOT aims at what's counted as a successful artifact and a satisfactory test of artifact (Kline and Pinch, 1996).

Out of three distinct combinations of works, SCOT grew. These works include: the early sciencetechnology-society (STS) movement, the sociology of scientific knowledge and the history of technology. The first started in the 1970s, mainly in the Netherlands, Scandinavia, the UK and the USA (Bijker, 2010).

\subsection{Criticisms of the Theory}

The major critics is of SCOT's view of society as composed of groups. It is argued that the particular way in which society is conceptualized and linked to artefacts is via the notion of relevant social groups (Pinch, 1996).Indirectly, SCOT assumes that groups are equal and that all relevant social groups are present in the design process (Klein and Kleinman, 2002). For power asymmetry between groups, this has been a failure as some groups may be effectively prevented from participating in the design process at all (Williams and Edge 1996). A Key element found to be missing in this approach would be the sociological enterprise. This approach has to do with artefacts and their relationships with the people whether conceived in terms of groups, actor network, or systems (Deborah, 2012).

Sociologists at time talk about structure and agency which are more complicated when dealing with technologies conceived in terms of human actors as being located within wider structures and the society in terms of structuring factors such as class, race, gender. They (sociologists) make use of the methodological technique such as social network approach and have conventional representations of macro structures somehow shaping the micro domains (Deborah, 2012). Also, there was a critique about SCOT's neglect on gender but was clarified when Cynthia Cockburn and Susan Omroyd brought up the idea that Pinch and Bijker drew the attention of the consideration of women as highly important to the social group of women bicyclist. The concept of 'actant' where both human and nonhuman entities could have agency is the distinction between human actor and the rest of the world. (Deborah, 2012)

Further, arguments against this theory have it that there was little to say about power in SCOT's theory and this was also a bridge where Pinch and Bijker stated that the strategic importance of reorienting technology studies back towards the artifact and away from social theory and so, no principle prevents the SCOT approach from considering power structure and social relationships between social groups (MacKenzie and Wajcman, 1985).

Social construction of technology also criticizes technological determinism and this comprises of two elements of which the first is; technology develops autonomously and secondly that technology determines an important degree societal development. Technological determinism implies a poor research strategy and this was argued because it entails a linear, teleological and one-dimension technological view of development (Wajcman, 2000).

The Social Construction of Technology comprises of the following aspects;

\subsection{Interpretive Flexibility of the Theory}

This refers to the way in which different groups of people involved in a technological have different understanding of that technology including the understanding of its technical characteristics. Wajcman, 2000). It is argued that the design of technology is an open process that can produce various outcomes and is dependent on the social circumstance of development (Pinch and Bijker, 1987); this argument distinguishes SCOT from other constructivist approach in the history of technology (Kline and Pinch, 1996).

\subsubsection{Wider Context of the Theory}

This is the wider social cultural and political milieu where the artefact development takes place and plays a minor role in Pinch and Bijkers's original conception of SCOT therefore, the rules governing the interaction of the social groups, relation to each other and the factors contributing to the differences in their power will remain invincible (Kline and Pinch, 1996). 


\subsection{Weakness of SCOT}

The development of SCOT was basically to deal mainly with the design stage of technologies. (Kline and Pinch, 1996). It is said that SCOT has analyzed a few part of the social structure and power relationships within which technological development takes place. Arising concerns are that the reciprocal relationship of the artefacts and social groups that have been neglected whereas, it is important to show how social groups identities are reconstituted in the economy and also how they come together to shape technology. (Kline and Pinch, 1996)

\section{CONCLUSION}

The theory of Social Construction of Technology attempts to present a framework that illuminate the influence of humans and their activities in shaping up of various technologies. Bijker in his paper describes that in a society a number of social groups exist which might have a different interpretation of an artifact such as technology.

These groups continue to develop the artifact until all groups have a consensus that the artifacts works for them (Klein \& Kleinman, 2002). Like Actor-Network Theory, the Social Construction of Technology theory also does not make use of the a priori information in its definition of influence of society and technology on each other (Klein \& Kleinman, 2002).

However, one of the major differences between Actor-Network Theory and Social Construction of Technology is the approach that these theories take in an attempt gain an understanding technology as a social phenomenon. Actor-Network Theory uses the concepts of actor and network and provides a framework to map semiotic as well as materialistic relationships. The actors are the object or artifacts found within the fabric of the society which form association with each other to form a network with other actors, which in turn defines them. These networks are Actor-Network Theory also advocates the abandoning of a priori information about the nature of networks. Actor-Network Theory also advocates free association, which means that it backs the idea of treating a natural and social phenomenon in the same way (Crawford, 2010).

The Social Construction of Technology Theory, on the other hand, takes a very different approach. Rather than treating a society an amalgamation of networks and actors, Social Construction of Technology uses interpretative flexibility to describe technological artifacts as products of negotiation between different social groups that exist within a society (Bijker Hughes, \& Pinch, 1989). Furthermore it argues that it is impossible to get a full understanding of technology without first possessing the knowhow of how technology is intertwined in the society (Bijker Hughes, \& Pinch, 1989). Though in Social Construction of Technology it is not claimed that social phenomenon have any preference over natural phenomenon but rather it is claimed that all phenomenon, social interests and artifacts are nothing but social (Bijker Hughes, \& Pinch, 1989).

\subsection{Proposed Theoretical Framework}

This study will be guided by a conceptual framework that represents the interrelationship among the variables to be used in the study. Various factors will act in combination to determine whether a cooperative society will use new media as a communication tool to enhance uptake of their services.

The dependent variables used in this study include reasons for using Social Media as a communication tool to enhance uptake of cooperative services; for example growth of technology in the world, competition in the market, ageing population of old cooperators, education levels of the youth, international trends on the adoption of ICTs in cooperatives, financial strengths of a cooperative society, ICT infrastructure of the cooperative society among others. The above factors contributing to use of new media technologies in cooperatives either independently or interdependently predispose a cooperative society to use of new media technologies as a communication tool.

The independent variable in this study is the New Media used by a co-operative society as a communication tool to enhance uptake of services.

The intervening variables in this study includes; the type of a co-operative society, the level of computer literacy/ sophistication of the management staff and management board, adherence to communication and marketing policies of the co-operative society, and adherence to ICT policies and 
existing legal frameworks like government policy on ICT, central bank regulations on banking,.

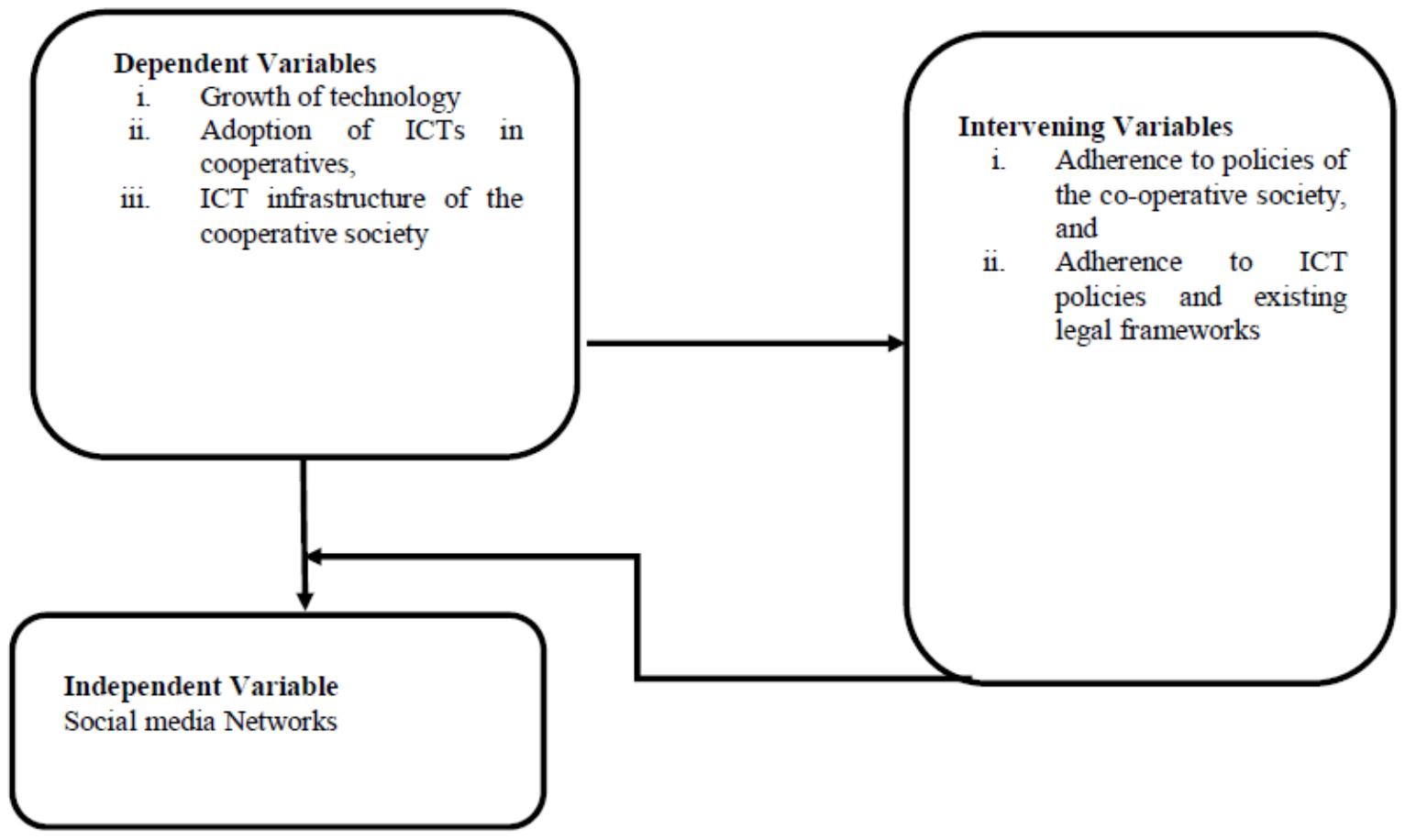

Figure1: Conceptual Framework

\subsection{Issues Addressed in the Theoretical Framework}

\subsubsection{The Concept of Communication}

There are two broad types of communication: verbal and non-verbal communication; of these, there is interpersonal communication which is the communication between two or more people in an organization (McQuail, 2002). Interpersonal communication includes various forms of communication, whether electronic, nonverbal or verbal key in any organization (Griffin, Et Al, 2014). The key elements in interpersonal communication are the communicator, the receiver, the perceptual screens, and the message. In communication, perceptual screens are defined as windows through which we interact with people that impact the quality, accuracy, and clarity of the communication (McQuail, 2002). The message contains the thoughts and feelings that the communicator intends to evoke in the receiver. Feedback in communication is an important loop, which occurs when the receiver provides the communicator with a response to the message (Griffin, Et Al, 2014).

\subsubsection{The Concept of Language}

It is argued that Language is one of the greatest inventions that man ever had in civilization and during prehistory. It is this discovery that over the years has made communication an innate aspect of humanity. Channels of communication however, have been in constant evolution just as language has been. Further, scholars have argued that Media, has, emerged out of growth of humanity and development since antiquity (P. Meiller 2009). It has become one of the major channels of communication henceforth; that notwithstanding, mainstream has been a domineering as a communication, which include broadcast media (Television and Radio) as well as print media (newspapers, reviews, magazines among others).

\subsection{Communicating Through Communication Technologies}

It has been observed that many people avoid written communication perhaps because they do not believe they are skilled in expressing their thoughts in writing. It is also considered less personal in many situations. Written communication has the advantage of high to moderate information capacity, but may also have the disadvantage of moderate to low information richness (McQuail, 2002).

Communication Technologies include electronic mails, voice mail, fax machines, tablets, iPads and 
cell phones. While these technologies greatly enhance the speed of communication, they cannot convey the nonverbal cues that make up a significant portion of the message therefore limiting sometimes the understanding of a message (Richard W. \& Lynn H., 2013).

It has been observed that communication technologies affect human communication behavior and continue to do overtime. For instance, these technologies are typically more impersonal, and may result in less patience with one-to-one communication as a much slower form of communication. New technologies provide the opportunity for us to multitask, which may have drawbacks when we need to focus closely on one problem at a time (McQuail, 2002). We can be overloaded with information and will need to be more conscious of filtering information (Richard \& Lynn, 2013).

\subsection{New Media as a Communication Tool}

Robert Logan in his book, Understanding New Media: Extending Marshall McLuhan defines new media as mediums that are interactive, incorporating two-way communication and involve some form of computing, He further argues that New media is "very easily processed, stored, transformed, retrieved, hyperlinked and, perhaps most radical of all, easily searched for and accessed." He argues that a distinction between new media and old media is that old media is for the most part mass media. In addition, each form of new media is highly interactive, while mass media is not. Users of new media are active producers of content and information, whether sending an email or using Internet collaboration tools (Logan, 2010).

New media theorist Lev Manovich describes new media as being native to computers or relying on computers for distribution: websites, human-computer interface, virtual worlds, virtual reality, multimedia, computer games, computer animation, digital video, special effects in cinema and interactive computer installations (Manovich, 2001).

Contrasted with the old media, the "old media," consists of mainly print, radio, and television/movies, we see that their presence in our lives and our societies was limited to a few places. For example, television and radio have long been key technology meant for mass consumption while new media, are, however, more personal and more social than old media (McQuail, 2002).

\subsection{Personal Media}

The term Personal media is used because users are more free to choose the content to which they want to expose, users are free to generate their own content, to comment on other users' contents, to share content with others, and more so generally to create personalized media communication environments. (Montfort, and Fruin, 2003). Personal computer is one of the devices that are used in a personal media context. In the late 1970s a personal computer was first produced and plans were in the works to create even more personal (and portable) computing devices (Lüders, 2008). The 1980s saw an explosion of personal media devices such as the Walkman, the VCR, the camcorder, the cell phone, and the personal computer. At some point in time, personal media devices lacked the connectivity that later allowed personal media to become social media. Then, people created personalized media environments that allowed for more control over the media messages with which they engaged. While the portable radios had been around for years, the 'Walkman' allowed people to listen to any cassette tape they owned instead of having to listen to whatever the radio station played (Siapera, 2012).

In this study, it was established that, the social media as a communication tool fostered a competitive advantage in positioning for their Co-operative societies. According to the study, Co-operatives which frequently uses social media communication tools in attracted customers and clients everytime.

Further, the study indicates that the current use of social media as a communication tool is an effective tool in responding to customer queries and complaints hence minimizing time for responses.

\section{REFERENCES}

[1] Beard, C. A., (1927). 'Time, Technology, and the Creative Spirit in Political Science'. In The American Political Science Review. Vol. 21, No. 1. NewYork: American Political Science Association.

[2] Benkler, Y. (2007), The Wealth of Networks: How Social Production Transforms Markets and Freedom, New Haven, CT: Yale University Press. 
[3] Bernasek, A. and Mongan, D. T. (2015), All You Can Pay: How Companies Use Our Data to Empty Our Wallets, New York: Nation Books.

[4] Bimber, B. 'Three faces of technological determinism'. In Roe Smith \& L. Marx. Ed. (1994) Does Technology Drive History? The Dilemma of Technological Determinism. USA: Massachusetts Institute of Technology.

[5] Bimber, Bruce. 1994. "Three Faces of Technological Determinism." in Does Technology Drive History, edited by Merrit Roe Smith and Leo Marx. Cambridge, MA: MIT Press.

[6] Boler, M., "Introduction," in Digital Media and Democracy: Tactics in Hard Times, ed. Megan Boler (Cambridge, MA: MIT Press, 2008), 39.

[7] Bollier, D. (2008), 'Inventing the creative commons', in Viral Spiral: How the Commoners Built a Digital Republic of Their Own, New York: The New Press.

[8] Boyd, D. M. and Nicole B. Ellison, "Social Network Sites: Definition, History, and Scholarship," Journal of Computer Mediated Communication 13, no. 1 (2008): 211.

[9] Brabham, D. C., "Crowd sourcing as a Model for Problem Solving: An Introduction and Cases," Convergence: The International Journal of Research into New Media Technologies 14, no. 1 (2008): 76.

[10] Brooks, R. A., (2002). 'Flesh and Machines: How Robots will change us. Reviewed by Phil Husbands. Cognitive and Computing Sciences. University of Sussex, UK: Pantheon Books.

[11] Ceruzzi, P. E. (2005). 'Moore's Law and Technological Determinism: Reflections on the History of Technology'. In Technology and Culture. Vol. 46. USA: John Hopkins University Press.

[12] Charles A. Beard, 1927 "Time, Technology, and the Creative Spirit in Political Science," 21 Am. Pol. Sci. Rev. 1, 5

[13] Co-operatives and Employment (produced by CICOPA in 2014 and 2017).

[14] Couldry, N. (2016), 'The price of connection: "surveillance capitalism"', The Conversation, September 22, available at: https://theconversation.com/the-price-of-connection-surveillance-capitalism-64124.

[15] Crowther, D. \& Lancaster, G. (2008), Research Methods (2nd Edition), Amazon

[16] Curl, J. (2012), For All the People: Uncovering the Hidden History of Cooperation, Cooperative Movements, and Communalism in America, 2nd ed., Oakland, CA: PM Press.

[17] Debra Corey (2016), Effective HR Communication: A Framework for Communicating HR programmes with impacts: Amazon digital services

[18] Dubash, M. (2005). Moore's Law is Dead. http://news.techworld.com/operating-systems/3477/mooreslaw-is-dead-says-gordon-moorel

[19] Ebert J.D, (2011), The New Media Invasion; New Media Technologies And The World The Unmake, McFarland \& company, Inc., publishers, Jefferson, north Carolina and London

[20] Ellul, J. (1964). The Technological Society. New York: Alfred A. Knopf

[21] Fasching, D. J. (1981). The thoughts of Jacques Ellul: A systematic Exposition. p. 17. New York: Edwin Mellen Press.

[22] FSD, Kenya 2015: http://fsdkenya.org/an-overview-of-m-pesa/

[23] Griffin ,E., Et Al (2014), A First Look at Communication Theory. McGraw-Hill, USA k

[24] Hatfield, Dale N. 1994. Speeding Telephone Service to Rural Areas: Lessons from the Experience in the United States. The Annenberg Washington Program in Communications Policy Studies of Northwestern University.

[25] Holyoake, George Jacob (1893). The History of the Rochdale Pioneers. London: Swan Sonnenschein \& Co. Retrieved 30 July 2009.

[26] Hoyt, Ann. 1982. "The Renaissance of Consumer Food Cooperatives: Sources of Growth, 1960-1980." Consumer Food Cooperatives: 1-31.

[27] http://cooperativecommons.coop/index.php/en/manifesto.

[28] http://ica.coop/en/facts-and-figures.

[29] http://ica.coop/en/whats-co-op/co-operative-identity-values-principles.

[30] http://internetofownership.net.

[31] http://platformcoop.net/2015/participants/maria-del-carmen-arroyo.

[32] Hunter, C., "Number of Facebook Users Could Reach 1 Billion by 2012," The Exponent Online, January 12, 2012, accessed November 8, 2012, http://www.purdueexponent.org/features/article_8815d757-8b7c566f-8fbe-49528d4d8037.html.

[33] International Journal of Multifaceted and Multilingual Studies, (2015) Assessing the Importance of Globalization and New Media Technology in 21st Century: An Analytical Overview 
[34] Kim Coontz, et al, (1995), Perceptions of Cooperatives: What They Mean to California's Cooperative Leaders, University of California

[35] Kimberly A. Zeuli \& Robert Cropp (2004), Cooperatives: Principles and Practices in the 21st Century, Cooperative Extension of the University of Wisconsin

[36] Kobia S.K. (2011), The Co-operative Movement in Kenya, Challenges and Opportunities; Lukiko consulting Publishers, Nairobi

[37] Kostakis, V. and Bauwens, M. (2014), Network Society and Future Scenarios for a Collaborative Economy, New York: Palgrave Macmillan.

[38] Lev Manovich, (2001): The Language of New Media, The Library of Congress, USA

[39] McQuail, Denis (2010), McQuails's Mass Communication Theory (sixth edition)

[40] McQuail, Denis (ed.) (2002), McQuail's reader in mass communication theory Sage, London

[41] O'Reilly, T., "What Is Web 2.0?" O'Reilly: Spreading the Knowledge of Innovators, accessed November 3, 2012, http://oreilly.com/web2/archive/what-is-web-20.html.

[42] Postman, N. (1993). Technopoly: The Surrender of Culture to Technology. New York: Vintage Books.

[43] Richard W. \& Lynn H. (2013), Introducing Communication Theory: Analysis and Application. McGraw Hill. USA

[44] Richardson, K. and Sue Hessey, "Archiving the Self?: Facebook as Biography of Social and Relational Memory," Journal of Information, Communication, and Ethics in Society 7, no. 1 (2009): 29.

[45] Robert K. Logan, (2010): Understanding New Media: Extending Marshall McLuhan., Peter Lang, USA

[46] Siapera, E., Understanding New Media (Thousand Oaks, CA: Sage, 2012), 3.

[47] Silberman, MS (2016), Reading Elinor Ostrom in Silicon Valley: Exploring Institutional Diversity on the Internet; ACM Conference Paper November 13-16, Sanibel Island, FL

[48] Smith \& Marx, Merrit Roe \& Leo (June 1994). Does Technology Drive History? The Dilemma of Technological Determinism. The MIT Press. ISBN978-0262691673.

[49] Vinge, V., (1993). 'The coming technological singularity: how to survive in the post-human era'. San Diego State University, California. In NASA Conference Publication 10129. Vision-21: Interdisciplinary Science and Engineering in the Era of Cyberspace. (pp. 274) Westlake, Ohio.

[50] ITU (International Telecommunication Union) (2010) ICT Statistics Newslog - National survey shows Kenyan Internet market heading towards "critical mass" http://www.itu.int/ITU-D/ict/newslog/National+ Survey+Shows+Kenyan+Internet+Market+Heading+Towards+Critical+Mass.aspx (viewed 6.6 2013)

[51] Kaplan, M. and Michael Haenlein (2010) 'Users of the world, unite! The challenges and opportunities of Social Media,' Business Horizons 53. pp 59-68.

[52] Murlidhar, Sid (2010) The Facebook Blog 'Fast and Free Facebook Mobile Access with 0.facebook.com' https://blog.facebook.com/blog.php?post=391295167130 (viewed 15.8. 2014)

Citation: Mwongela Francis, et.al. "The Potential of Social Media as a Communication Tool among CoOperative in Kenya: A Review of Literature". International Journal of Media, Journalism and Mass Communications (IJMJMC), vol 5, no. 2, 2019, pp. 31-45 doi: http://dx.doi.org/10.20431/2455-0043.0502005

Copyright: () 2019 Authors. This is an open-access article distributed under the terms of the Creative Commons Attribution License, which permits unrestricted use, distribution, and reproduction in any medium, provided the original author and source are credited. 